\title{
Macro-Autoradiographic Studies on North Sea Sediment Bacteria
}

\author{
M. Rieper \\ Biologische Anstalt Helgoland, D-2192 Helgoland, Federal Republic of Germany
}

\begin{abstract}
Using ${ }^{14} \mathrm{C}$-labelled substrates it was shown that $>80 \%$ of the saprophytic bacteria populations of North Sea sublittoral and littoral sediments have uptake mechanisms for glucose, glucosamine, sodium acetate and aspartic acid. One third are able to utilize glycollic acid whereas only a small fraction degrades fat, phenol and uric acid. Yellow and orange pigmented colonies frequently occur. The numbers of saprophytic bacteria lie within the range of $10^{4}-10^{6}$ (g dry sediment) ${ }^{-1}$, with the highest amounts found in the sublittoral sediments with the finest mean particle size. On the beach the greatest amounts of bacteria were found in the mudflats as opposed to the beach slope. There was no apparent correlation between the distribution of the saprophytic bacteria and the meiofauna present in these sediments.
\end{abstract}

\section{INTRODUCTION}

The studies described in this work were undertaken in order to investigate the different physiological groups as well as amounts of saprophytic bacteria available as potential food sources for the meiofauna in different sediment habitats. It has already been shown in laboratory experiments that meiofauna (commonly referring to small sediment-dwelling metazoans which pass a $1 \mathrm{~mm}$ sieve but are retained by a $40 \mu \mathrm{m}$ sieve). such as nematodes and copepods, ingest large quantities of bacteria (Duncan et al., 1974; Brown and Sibert, 1977) but are also able to grow and reproduce on an exclusive diet of bacteria (Rieper, 1978). In order to meet their nutritional requirements in nature, it is probable that many meiofauna animals depend on bacteria and some may have developed unusual mechanisms to ensure a continuous food supply (Gerlach, 1978; Riemann and Schrage, 1978; Hicks and Grahame, 1979). ZoBell and Feltham (1942, p. 76) stated: "It is believed that detailed observations on the numbers and kinds of bacteria in localized areas may often help to explain the presence or absence of the fauna and flora of these areas."

Microbiological investigations were carried out in 1977-1978 on the uppermost layers of marine sediments - where not only the highest bacteria numbers but also the greatest meiofauna densities may be found - from different biotopes in the North Sea. These included various sublittoral sediments near the island of
Helgoland (Fig. 1) and a tidal sandy beach including the mudflats of the island Sylt (Fig. 2). Sampling areas were chosen in which the meiofauna and other properties of the sediments had already been investigated (Schmidt, 1968, 1969; Stripp, 1969a, b; see also Weyland, 1967; Hickel and Gunkel, 1968; Westheide, 1968; Rheinheimer, 1977 for earlier studies on North Sea sediment bacteria). In addition to the quantitative investigations on the saprophytic bacteria with the spread plate method, macro-autoradiographic studies were carried out to determine the occurrence and distribution of the different physiological types of bacteria according to their substrate preferences. This represents the first time that the macro-autoradiographic method has been used with sediment bacteria.

\section{MATERIAL AND METHODS}

\section{Description of the Study Areas and Sampling Procedures}

\section{Helgoland}

From January 1977 to February 1978 monthly samples were taken from sublittoral sediments at 3 stations near Helgoland by means of a box grab. Approximately $100 \mathrm{~g}$ fresh sediment were removed from the uppermost $2 \mathrm{~cm}$ of the surface and stored in a cool place on board the research vessel "Uthörn" until 


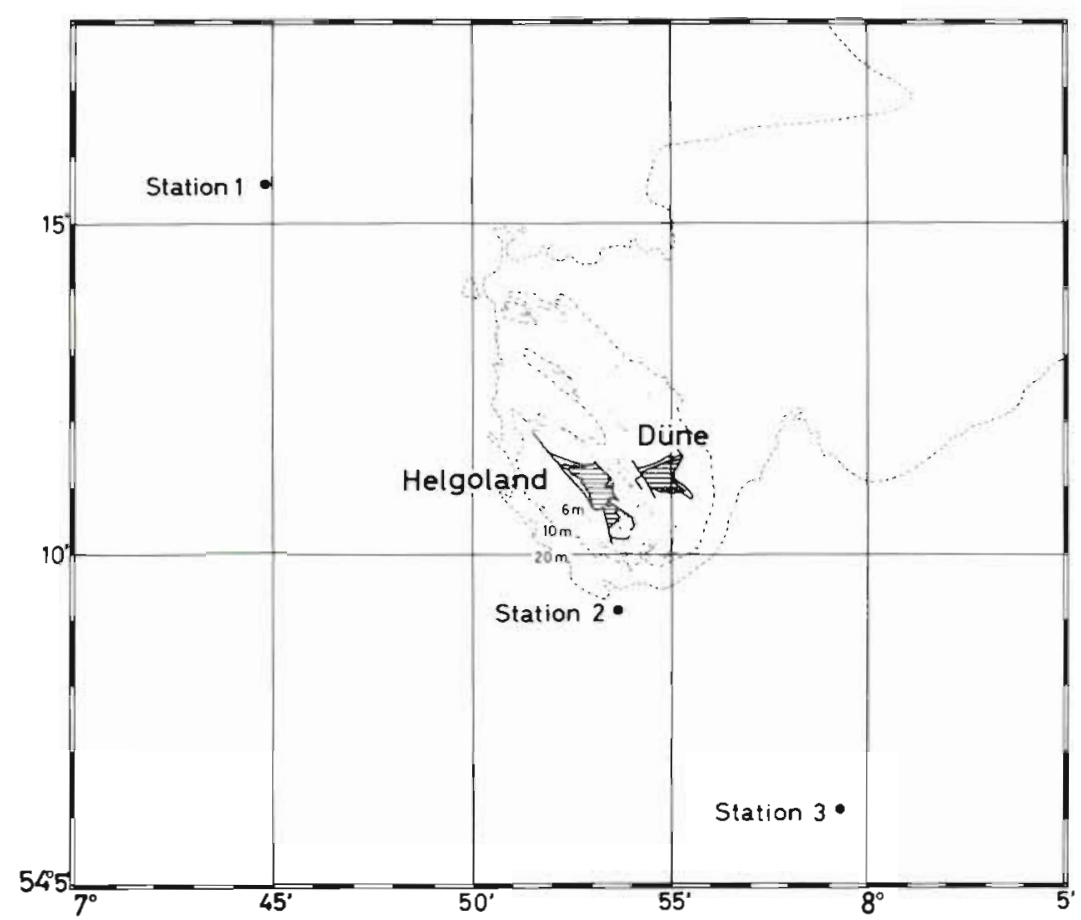

Fig. 1. Area of the North Sea island Helgoland including the locations of the 3 stations from which samples were taken

further use. The maximum time interval from sampling until return to the laboratory was $3 \mathrm{~h}$. Immediately upon return the samples were diluted and spread plates prepared. The following descriptions of the sediments are according to analyses made by Stripp (1969a), whereby our Stations 1, 2 and 3 correspond to Stripp's original designations $3 \mathrm{~S}, \mathrm{AH}$ and $\mathrm{H} 2$, respectively. Decca navigation was used to locate the stations.

Station 1: $54^{\circ} 15.6^{\prime} \mathrm{N}, 7^{\circ} 44.8^{\prime} \mathrm{E}$, depth $33 \mathrm{~m}$.

Sediment analysis: sandy silt, median grain size $92 \mu \mathrm{m}$.

Station 2: $54^{\circ} 09.1^{\prime} \mathrm{N}, 7^{\circ} 53.5^{\prime} \mathrm{E}$, depth $49 \mathrm{~m}$.

Sediment analysis: heterogeneous fine to coarse sand, median grain size $345 \mu \mathrm{m}$.

Station 3: $54^{\circ} 06.1^{\prime} \mathrm{N}, 7^{\circ} 59.2^{\prime} \mathrm{E}$, depth $30 \mathrm{~m}$.

Sediment analysis: heterogeneous fine sand and mud, median grain size $72 \mu \mathrm{m}$.

\section{List/Sylt}

Samples from the sandy beach at List/Sylt were taken at maximum low tide at the following stations (Fig. 3): (1) zero mark, point at which the beach slope joins the mudflat area; (2) $10 \mathrm{~m}$ mudflat; (3) $25 \mathrm{~m}$ mudflat; (4) $10 \mathrm{~m}$ on the beach slope. The study area is located directly below the old research station ("Haus $\mathrm{C}^{\prime \prime}$ ) of the Biologische Anstalt Helgoland (Litoralstation). Samples were taken from the uppermost $2 \mathrm{~cm}$ of

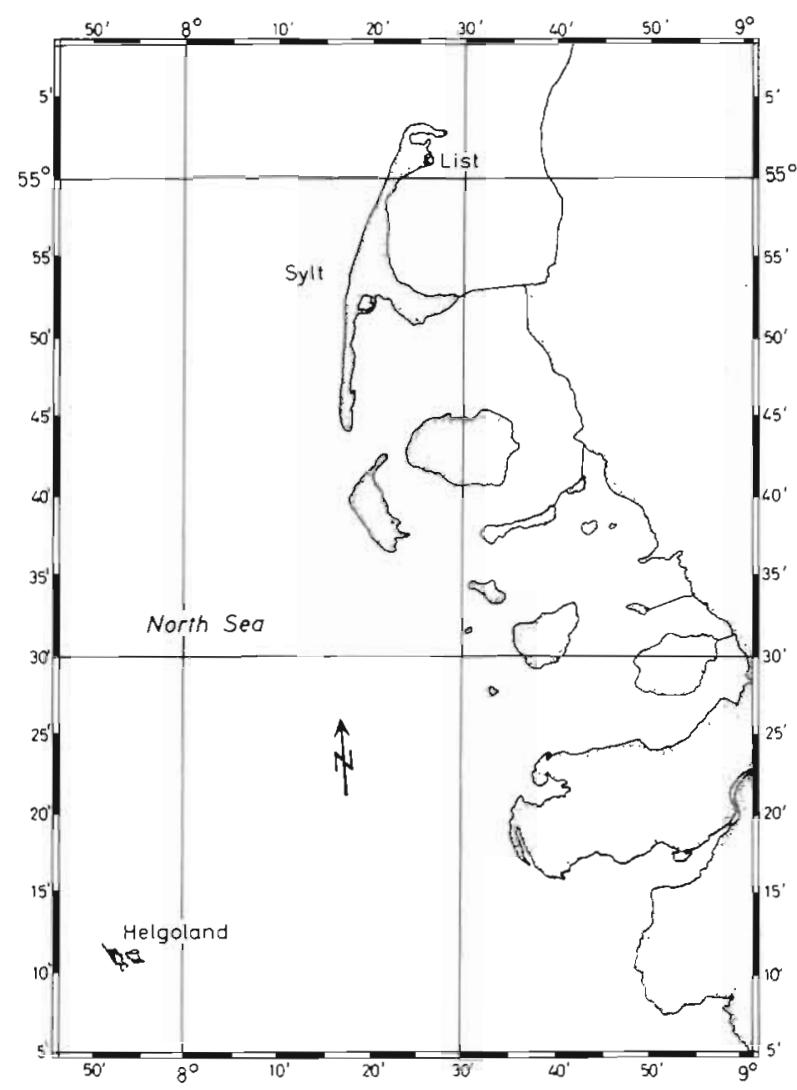

Fig. 2. Area of the North Sea island Sylt. The sandy beach studied is near List 


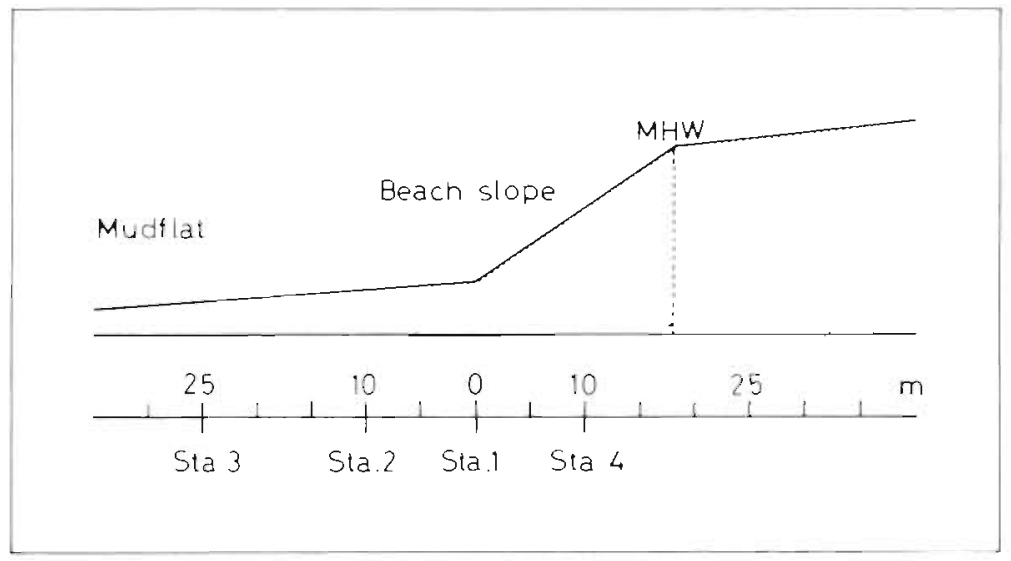

Fig. 3. Schematic diagram of sandy beach at List/Sylt. (After Ax and Schmidt, in Schmidt, 1968; modified). MHW: mean high water

the sediment surface. Since the distance from the beach to the laboratory was very short, the samples could be treated immediately. Sediments at all stations are composed of relatively detritus-poor loose quartz sand. Approximately $70 \%$ of the sand grains have a size between 350-700 $\mu \mathrm{m}$ (Westheide, 1968).

\section{Determining the Numbers of Saprophytic Bacteria}

The spread plate method was used to determine the numbers of viable saprophytic bacteria in the sediment samples (Gunkel and Rheinheimer, 1968). From the original samples $2 \mathrm{~cm}^{3}$ fresh sediment were removed by means of a sterile syringe which had been cut off at one end. This was added to $98 \mathrm{ml}$ autoclaved aged seawater and distilled water at a mixture of $3: 1$. All samples were shaken vigorously by hand for $2 \mathrm{~min}$, since the commonly used ultra-turrax method (Gunkel, 1974) was unsuitable for sediments containing very coarse sand and shell fragments. From appropriately diluted samples $0.1 \mathrm{ml}$ aliquots were inoculated onto agar plates prepared with medium 2216 E (Oppenheimer and ZoBell, 1952). The plates were incubated 14 days at $20^{\circ} \mathrm{C}$. The two most suitable dilutions were used in the final colony counts. Dry weights were determined from aliquots of the same sediment samples which were used for the saprophytic bacteria determinations.

Temperature measurements were made on samples of surface water at the stations near Helgoland, and on the moist beach sand at List from where the samples were taken.

\section{Macro-Autoradiography}

The macro-autoradiographic method of Hoppe $(1974,1977)$ was used in order to determine the physio- logical groups of active, saprophytic bacteria colonies. The technique was modified by raising the salinity of the media from $15 \%$ to $24 \%$ for marine bacteria. The following ${ }^{14} \mathrm{C}$-labelled substrates were used in the investigations: glucose, aspartic acid, sodium acetate, glucosamine, glycerol tripalmitate, phenol, uric acid, and glycollic acid (obtained from Amersham Buchler, Braunschweig, FRG). From sediment samples diluted as above, $10 \mathrm{ml}$ aliquots were filtered through $0.2 \mu \mathrm{m}$ membrane filters. The filters were then pre-incubated $5-6 \mathrm{~d}$ at $20^{\circ} \mathrm{C}$ on pads soaked in liquid ZoBell $2216 \mathrm{E}$ medium until colonies were clearly visible; they were then transferred to filter paper discs moistened with $0.5 \mu \mathrm{Ci}$ (=0.75 ml) ${ }^{14} \mathrm{C}$-substrate. After $2 \mathrm{~d}$ incubation at $20^{\circ} \mathrm{C}$ with the labelled substrates, the membrane filters were carefully washed to remove excess substrate, dried overnight at room temperature, and then exposed to X-ray film for $2 \mathrm{~d}$ in a light-proof box. The developing and washing procedures are described in Hoppe (1974).

The black spots on the film correspond to bacteria colonies on the membrane filters which were able to utilize a given substrate. Thus the percentage of saprophytic bacteria with uptake properties for that substrate can be calculated. Special attention was given to pigmented colonies and their substrate preferences. To facilitate counting, the membrane filters were later stained with erythrosin $(2 \%$ erythrosin in a $5 \%$ phenol solution) and dried overnight at room temperature.

\section{RESULTS}

\section{Numbers of Saprophytic Bacteria}

Helgoland

The numbers of saprophytic bacteria found in the different sediments from 3 stations near Helgoland are 
shown in Figure 4 and Table 1. The largest amounts of bacteria are found at Station 3, where the sediment is composed mainly of very fine sand and mud and has the smallest median grain size. At Station 2, where the

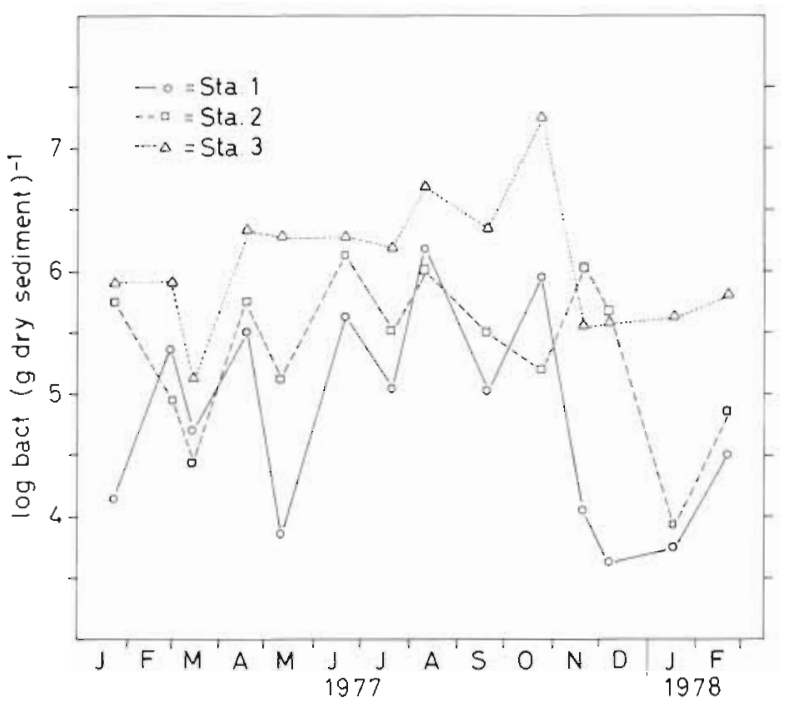

Fig. 4. Numbers of saprophytic bacteria (g dry sediment) ${ }^{-1}$ found in monthly samples taken from 3 stations near Helgoland (spread plate method) sediment consists predominantly of coarse sand and shell fragments, the bacteria counts were lower than at Station 3 , often by a factor of ten. The lowest numbers were found at Station 1 which has a silty sand sediment. The mean values for a sampling period of 14 months are $2.5 \times 10^{6}$ (g dry sediment) $)^{-1}$ for Station 3 , followed by $0.4 \times 10^{6} \mathrm{~g}^{-1}$ for Station 2 and $0.3 \times 10^{6} \mathrm{~g}^{-1}$ for Station 1. In general, the amounts of saprophytic bacteria are higher during the warmer months of the year and lower from November to March, although considerable fluctuations occur independent of the water temperature (Table 3 ). The proportion of pigmented bacteria colonies on the agar plates fluctuates between 2 and $89 \%$ (Fig. 5). Maxima occur in June-July and October-November. At these times the majority of the bacteria colonies found on the agar plates were yellow or orange; this points to a high bacteria population density consisting of only a few species. Besides orange and yellow forms and colors ranging between yellow-orange and ochre, also red, pink and brown froms were found but much less frequently. Colonies with other pigmentation were rare.

Generally speaking, consiedering some differences in the methods employed, the results pertaining to the numbers of saprophytic bacteria are on the same order

Table 1. Total saprophytic bacteria numbers for the uppermost sediment layers at the Stations 1, 2 and 3 near Helgoland, expressed for $1 \mathrm{~g}$ dry sediment and for $1 \mathrm{~cm}^{3}$ fresh sediment, respectively

\begin{tabular}{|c|c|c|c|c|c|c|}
\hline \multirow[t]{2}{*}{ Date } & \multicolumn{2}{|c|}{ Station 1} & \multicolumn{2}{|c|}{ Station 2} & \multicolumn{2}{|c|}{ Station 3} \\
\hline & $1 \mathrm{~g}$ & $1 \mathrm{~cm}^{3}$ & $1 \mathrm{~g}$ & $1 \mathrm{~cm}^{3}$ & $1 \mathrm{~g}$ & $1 \mathrm{~cm}^{3}$ \\
\hline Jan. 24, 1977 & 13700 & 22300 & 545000 & 698000 & 781000 & 641000 \\
\hline Mar. 1, 1977 & 228000 & 401000 & 78500 & 123000 & 806000 & 580000 \\
\hline Mar. 15, 1977 & 51600 & 78800 & 27000 & 33800 & 135000 & 98800 \\
\hline Арr. 19, 1977 & 324000 & 512000 & 560000 & 823000 & 2080000 & 1623000 \\
\hline May 11,1977 & 7200 & 11600 & 134000 & 199000 & 1900000 & 1681000 \\
\hline June 21, 1977 & 431000 & 721000 & 1329000 & 2200000 & 1839000 & 1600000 \\
\hline July 21,1977 & 110000 & 201000 & 324000 & 505000 & 1541000 & 1125000 \\
\hline Aug. 11, 1977 & 1516000 & 2850000 & 1027000 & 1725000 & 4697000 & 4650000 \\
\hline Sept. 20, 1977 & 106000 & 173000 & 324000 & 475000 & 1250000 & 1025000 \\
\hline Oct. 25,1977 & 908000 & 1425000 & 162000 & 238000 & 18240000 & 11680000 \\
\hline Nov. 21,1977 & 11400 & 21300 & 1069000 & 1850000 & 361000 & 325000 \\
\hline Dec. 7,1977 & 4200 & 6000 & 469000 & 568000 & 384000 & 280000 \\
\hline Jan. 18, 1978 & 56100 & 90000 & 84500 & 118000 & 429000 & 348000 \\
\hline Feb. 21,1978 & 32100 & 50000 & 71400 & 108000 & 650000 & 413000 \\
\hline
\end{tabular}

Table 2. Total saprophytic bacteria numbers for the uppermost sediment layers at 4 stations from the sandy beach at List/Sylt, expressed for $1 \mathrm{~g}$ dry sediment and $1 \mathrm{~cm}^{3}$ fresh sediment, respectively

\begin{tabular}{|c|c|c|c|c|c|c|c|c|}
\hline \multirow[t]{2}{*}{ Date } & \multicolumn{2}{|c|}{ Station 1} & \multicolumn{2}{|c|}{ Station 2} & \multicolumn{2}{|c|}{ Station 3} & \multicolumn{2}{|c|}{ Station 4} \\
\hline & $1 \mathrm{~g}$ & $1 \mathrm{~cm}^{3}$ & $1 \mathrm{~g}$ & $1 \mathrm{~cm}^{3}$ & $1 \mathrm{~g}$ & $1 \mathrm{~cm}^{3}$ & $1 \mathrm{~g}$ & $1 \mathrm{~cm}^{3}$ \\
\hline Mar. 8, 1977 & 23200 & 35300 & 111000 & 167000 & 334000 & 497000 & 22700 & 31800 \\
\hline Арг. 6, 1977 & 10000 & 15800 & 71700 & 108000 & 106000 & 169000 & 34200 & 47800 \\
\hline May 4, 1977 & 114000 & 184000 & 1048000 & 1630000 & 956000 & 1478000 & 29200 & 41800 \\
\hline Sept. 1, 1977 & 113000 & 193000 & 474000 & 735000 & 186000 & 293000 & 5955000 & 9350000 \\
\hline Dec. 5,1977 & 80000 & 112000 & 801000 & 1234000 & 866000 & 1334000 & 79100 & 112000 \\
\hline
\end{tabular}


Table 3. Average temperature of surface water from 3 stations near Helgoland from January 1977 to February 1978, and of the moist sand surface at 4 stations from the beach at List/Sylt during five samplings in 1977

\begin{tabular}{|lc|}
\hline Sampling date & $\begin{array}{c}\text { Temperature } \\
\left({ }^{\circ} \mathrm{C}\right)\end{array}$ \\
\hline Jan. 24, 1977 & 4.1 \\
Mar. 1, 1977 & 3.6 \\
Mar. 15, 1977 & 3.8 \\
Apr. 19, 1977 & 5.2 \\
May 11, 1977 & 7.8 \\
June 21, 1977 & 11.2 \\
July 21, 1977 & 15.1 \\
Aug. 11, 1977 & 15.7 \\
Sept. 20,1977 & 15.7 \\
Oct. 25, 1977 & 13.8 \\
Nov. 21, 1977 & 10.0 \\
Dec. 7, 1977 & 7.9 \\
Jan. 18, 1978 & 4.5 \\
Feb. 21, 1978 & 2.8 \\
Mar. 3, 1977 & \\
Apr. 6, 1977 & 7.3 \\
May 4, 1977 & 7.8 \\
Sept. 1, 1977 & 11.5 \\
Dec. 5, 1977 & 19.1 \\
& 0.15 \\
\hline
\end{tabular}

of magnitude as those found by Weyland (1967) and Hickel and Gunkel (1968) during earlier investigations on North Sea sediment bacteria. In samples taken from sediments near the stations described here, Weyland (1967) also found the highest numbers of saprophytic bacteria in muddy sediments $\left(6.4 \times 10^{6} \mathrm{ml}^{-1}\right)$ compared to those in silty sand $\left(1.0 \times 10^{6} \mathrm{ml}^{-1}\right)$ and in coarse sand $\left(0.1 \times 10^{6} \mathrm{ml}^{-1}\right)$.

As in sublittoral sediments near Helgoland, the numbers of saprophytic bacteria occurring in sands from mudflats and beach slope at List/Sylt generally lie within the range of $10^{4}$ to $10^{6}$ ( $\mathrm{g}$ dry sediment) ${ }^{-1}$ (Fig. 6 and Table 2). The highest numbers of bacteria were found at Stations 2 and 3 , both of which lie in the mudflat area, where the bacteria counts were at times greater than those on the lower and middle beach slope by a factor of ten or more. This confirms earlier results of Westheide (1968) who also found the maximum numbers of saprophytic bacteria in the mudflats of List compared to those on the lower beach slope. The relatively high value of over 6 million colonies $\mathrm{g}^{-1}$ at Station 4 in September 1977 may be due to a local high concentration, and is not representative for the area. It should be mentioned here that higher values have been found in surface sediments from the supralittoral zones of North Sea beaches: values ranging from $10^{6}$ to $10^{7}\left(\mathrm{~cm}^{3}\right.$ fresh sediment) ${ }^{-1}$ have been found by Westheide (1968) and Rheinheimer (1977). Using fluorescence microscopy on a sediment sample from the supralittoral at St. Peter-Ording, Weise and Rheinheimer (1979) found total bacteria counts of $10^{8}\left(\mathrm{~cm}^{3}\right.$ fresh sediment $)^{-1}$. Since sediment samples from List were taken only 5 times during the year 1977, a clear seasonal cycle cannot be described. The numbers of saprophytic bacteria in March and April were generally lower than those occurring in May, September and December. The percentage of pigmented bacteria colonies (Fig. 7) was higher in December than in the other months. From samples taken at all 4 stations in December 1977, more than half of the bacteria colonies

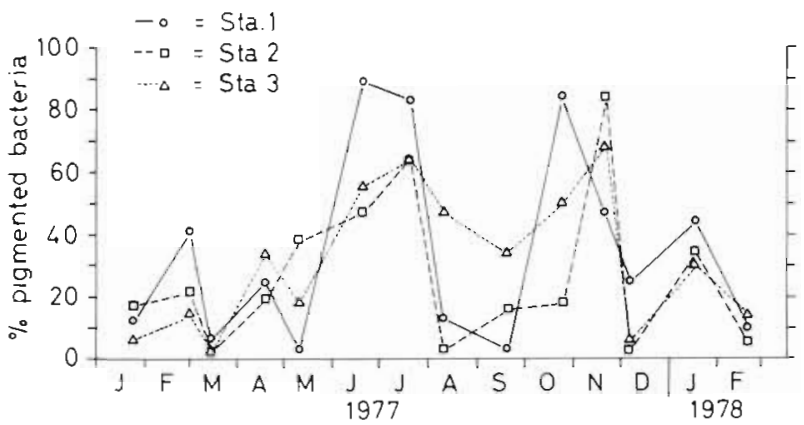

Fig. 5. Percentage of pigmented bacteria colonies of the total saprophytic bacteria occurring in the same samples

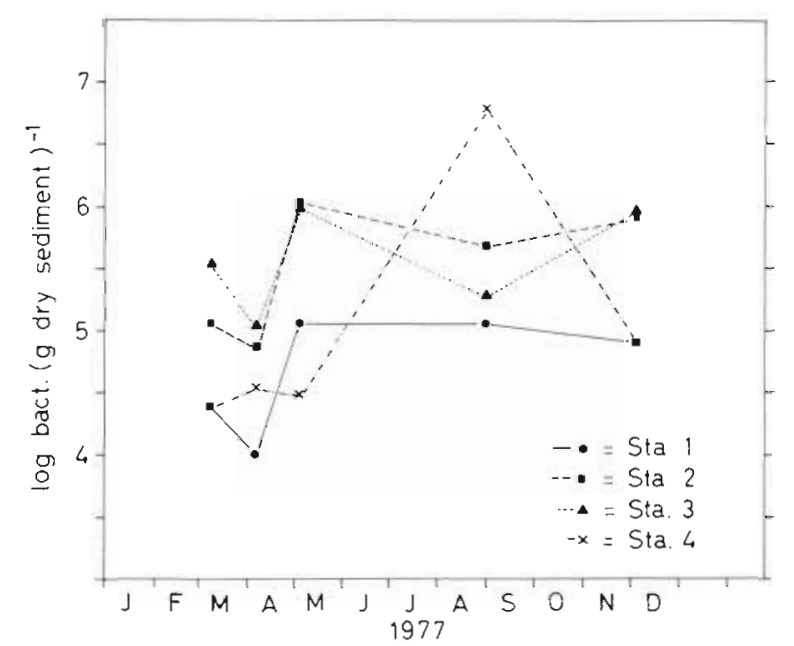

Fig. 6. Numbers of saprophytic bacteria ( $\mathrm{g}$ dry sediment) ${ }^{-1}$ found in samples taken from the sandy beach at List/Sylt (spread plate method)

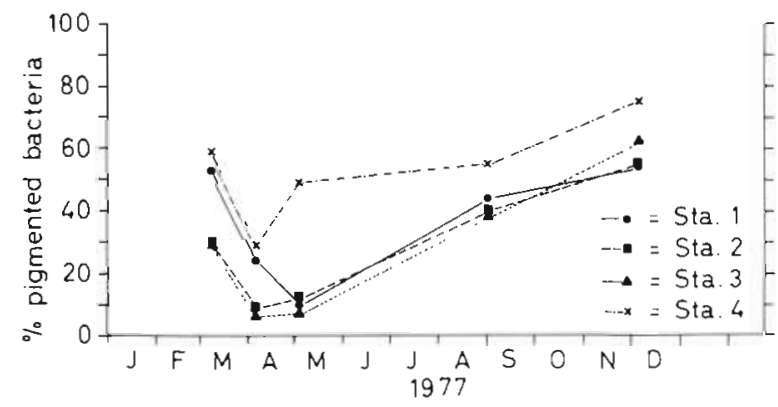

Fig. 7. Percentage of pigmented bacteria colonies of the total saprophytic bacteria occurring in the same samples 
Table 4. Proportion of total saprophytic bateria populations from sublittoral sediments near Helgoland which are able to utilize a given ${ }^{14} \mathrm{C}$-labelled substrate. Maximum and minimum values, as well as the mean (in parentheses), are given for all samples taken

\begin{tabular}{|c|c|c|c|}
\hline Substrate & Sta. 1 (Sandy silt) & Sta. 2 (Coarse sand) & Sta. 3 (Very fine sand, mud) \\
\hline . Glucose & $\begin{array}{c}94-100 \% \\
(99)\end{array}$ & $\begin{array}{c}87-100 \% \\
(97)\end{array}$ & $\begin{array}{c}88-100 \% \\
(97)\end{array}$ \\
\hline Glucosamine & $\begin{array}{c}90-100 \% \\
(97)\end{array}$ & $\begin{array}{c}86-100 \% \\
(95)\end{array}$ & $\begin{array}{c}96-100 \% \\
(99)\end{array}$ \\
\hline Sodium acetate & $\begin{array}{c}88-100 \% \\
(94)\end{array}$ & $\begin{array}{c}31-99 \% \\
(85)\end{array}$ & $\begin{array}{c}94-100 \% \\
(97)\end{array}$ \\
\hline Aspartic acid & $\begin{array}{c}40-100 \% \\
(87)\end{array}$ & $\begin{array}{c}44-99 \% \\
(81)\end{array}$ & $\begin{array}{c}42-99 \% \\
(85)\end{array}$ \\
\hline Glycollic acid & $\begin{array}{c}0-66 \% \\
(32)\end{array}$ & $\begin{array}{c}0-60 \% \\
(35)\end{array}$ & $\begin{array}{c}11-72 \% \\
(33)\end{array}$ \\
\hline Glycerol tripalmitate & $\begin{array}{c}0-26 \% \\
(11)\end{array}$ & $\begin{array}{c}5-34 \% \\
\text { (15) }\end{array}$ & $\begin{array}{c}2-25 \% \\
(16)\end{array}$ \\
\hline Uric acid & $\begin{array}{c}3-25 \% \\
(10)\end{array}$ & $\begin{array}{c}0-16 \% \\
(8)\end{array}$ & $\begin{array}{c}3-21 \% \\
(8)\end{array}$ \\
\hline Phenol & $\begin{array}{c}0-27 \% \\
(6)\end{array}$ & $\begin{array}{c}1-9 \% \\
(4)\end{array}$ & $\begin{array}{c}2-13 \% \\
(6)\end{array}$ \\
\hline
\end{tabular}

Table 5. Proportion of total saprophytic bacteria populations from sandy littoral sediments at List/Sylt which are able to utilize a given ${ }^{14} \mathrm{C}$-labelled substrate. Maximum and minimum values, as well as the mean (in parentheses), are given for all samples taken

\begin{tabular}{|c|c|c|c|c|}
\hline Substrate & $\begin{array}{c}\text { Sta. } 1 \\
\text { (Bottom slope) }\end{array}$ & $\begin{array}{c}\text { Sta. } 2 \\
(10 \mathrm{~m} \text { mudflat })\end{array}$ & $\begin{array}{c}\text { Sta. } 3 \\
\text { (25 m mudflat) }\end{array}$ & $\begin{array}{c}\text { Sta. } 4 \\
(10 \mathrm{~m} \text { slope })\end{array}$ \\
\hline Glucose & $\begin{array}{c}99-100 \% \\
(100)\end{array}$ & $\begin{array}{c}96-100 \% \\
(99)\end{array}$ & $\begin{array}{c}98-100 \% \\
(99)\end{array}$ & $\begin{array}{c}97-100 \% \\
(99)\end{array}$ \\
\hline Sodium acetate & $\begin{array}{c}85-100 \% \\
(94)\end{array}$ & $\begin{array}{c}91-100 \% \\
(96)\end{array}$ & $\begin{array}{c}94-100 \% \\
(96)\end{array}$ & $\begin{array}{c}89-100 \% \\
(96)\end{array}$ \\
\hline Glucosamine & $\begin{array}{c}81-100 \% \\
(92)\end{array}$ & $\begin{array}{c}90-98 \% \\
(95)\end{array}$ & $\begin{array}{c}88-90 \% \\
(89)\end{array}$ & $\begin{array}{c}77-97 \% \\
(87)\end{array}$ \\
\hline Aspartic acid & $\begin{array}{c}52-100 \% \\
(82)\end{array}$ & $\begin{array}{c}59-98 \% \\
(81)\end{array}$ & $\begin{array}{c}83-93 \% \\
(90)\end{array}$ & $\begin{array}{c}93-98 \% \\
(96)\end{array}$ \\
\hline Glycollic acid & $\begin{array}{c}17-59 \% \\
(36)\end{array}$ & $\begin{array}{c}16-42 \% \\
(29)\end{array}$ & $\begin{array}{c}20-49 \% \\
(32)\end{array}$ & $\begin{array}{c}20-49 \% \\
(38)\end{array}$ \\
\hline Uric acid & $\begin{array}{c}11-31 \% \\
(22)\end{array}$ & $\begin{array}{c}7-15 \% \\
(12)\end{array}$ & $\begin{array}{c}8-14 \% \\
(11)\end{array}$ & $\begin{array}{c}6-20 \% \\
(13)\end{array}$ \\
\hline Phenol & $\begin{array}{c}0-4 \% \\
(2)\end{array}$ & $\begin{array}{c}0-14 \% \\
(5)\end{array}$ & $\begin{array}{c}0-10 \% \\
\text { (4) }\end{array}$ & $\begin{array}{c}0-27 \% \\
(13)\end{array}$ \\
\hline Glycerol tripalmitate & $\begin{array}{c}2-5 \% \\
\text { (4) }\end{array}$ & $\begin{array}{c}1-5 \% \\
(3)\end{array}$ & $\begin{array}{c}3-4 \% \\
\text { (4) }\end{array}$ & $\begin{array}{c}2-11 \% \\
(7)\end{array}$ \\
\hline
\end{tabular}

on the agar plates were pigmented yellow or orange. Brown, pink, red and violet colonies occurred less frequently; other colors were rare. The highest proportions of pigmented colonies were found at Station 4 on the middle beach slope zone which was exposed longest during the change of the tide.

\section{Macro-Autoradiographic Studies on the Bacteria Populations}

The percentage of bacteria from the Helgoland sediments which are able to utilize a given labelled sub- strate are listed in Table 4 . The maximum and minimum as well as the average values (in parentheses) for the period investigated are given. " The order of preference for the substrates shown by the bacteria according to their nutritional demands is as follows: glucose and glucosamine, average uptake values all above $95 \%$; sodium acetate, over $85 \%$ uptake, followed by

\footnotetext{
- In the case of glycerol tripalmitate measurements were made only during the 8 months between August 1977 and February 1978; for phenol, uric acid and aspartic acid 11 monthly samples were taken, and 12 for all remaining substrates.
} 
aspartic acid ( $>80 \%$ ); glycollic acid $32-35 \%$ with strong fluctuations regardless of station and season; glycerol tripalmitate, 11 to $16 \%$; uric acid, 8 to $10 \%$; phenol, 4 to $6 \%$. The fluctuations occurring from one sampling period to the next were too great to determine if significant differences were present in the substrate uptake by bacteria in different sediments. No pronounced seasonal cycle was recognized, although the uptake values for uric acid and aspartic acid tended to be higher during the colder months, particularly in silty sand (Station 1) and coarse sand sediments (Station 2). The unusually low uptake values for sodium acetate at Station 2 in April and May may have been due to local disturbances at the sediment surface.

The substrate preferences of bacteria from the beach at List are similar to those from the sublittoral near Helgoland (Table 5). Average uptake values for glucose and sodium acetate were between 94 and nearly $100 \%$ of the saprophytic bacteria populations. A relatively high percentage was also able to utilize glucosamine $(87-95 \%)$ and aspartic acid $(81-96 \%)$, whereby the values for glucosamine, a component of chitin, were less than those found for the Helgoland sediment bacteria. The highest proportion of the bacteria from the beach at List which were able to utilize aspartic acid $(>96 \%)$ occurred on the middle beach slope at Station 4, compared to those at the bottom of the slope or in the mudflat area. Glycollic acid, an extracellular product of many algae, was taken up by approximately $1 / 3$ of the bacteria in all sediments studied. Uric acid (excreted by birds) was utilized by a greater proportion of the bacteria from List (11-22\%) than those from the sublittoral sediments near Helgoland. The percentage of phenol-degrading bacteria both from List and Helgoland remained relatively small $(2-13 \%)$ with the highest values found in samples from the middle beach slope. The substrate which was taken up by the smallest percentage of the bacteria from List was glycerol tripalmitate (fat) with average values of only $3-7 \%$ of the saprophytic bacteria population; the values determined for the sublittoral sediments near Helgoland, on the other hand, were 2 to 5 times greater.

Using the macro-autoradiographic method, Hoppe (1974) found that the proportions of the saprophytic bacteria populations in the water of the Kiel Fjord (western Baltic Sea) which were able to utilize uric acid, fat, phenol and sodium acetate decrease with increasing distance from the shore. With regard to the present investigations on North Sea sediment bacteria, however, this effect was not noticeable (considering the stations near Helgoland as shore-distant), although it is possible that the strong fluctuations in the uptake values could have masked small changes occurring in the bacteria populations. The percentages of physiological groups of saprophytic bacteria found in the Baltic

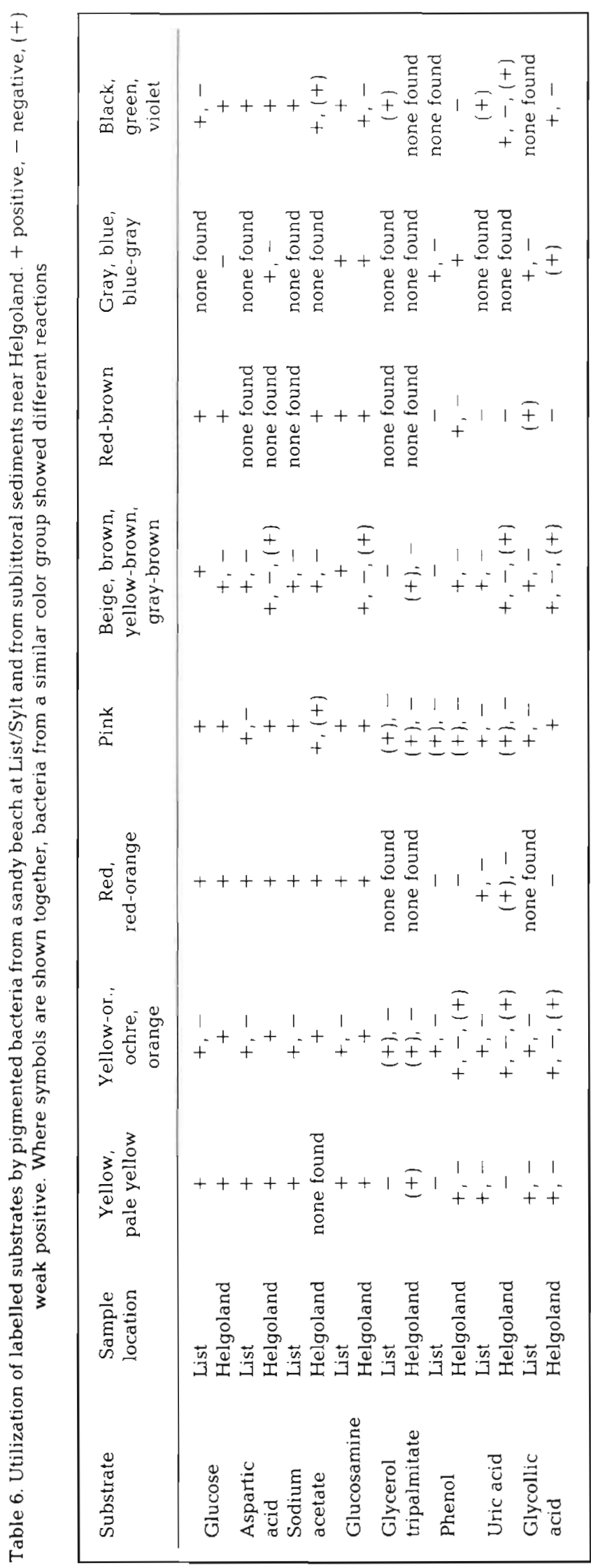


Sea water by Hoppe (1974) are on the whole comparable to those reported here for North Sea sediments.

As shown in Table 6, the most versatile pigmented bacteria colonies found in samples from the sublittoral sediments were among those with orange or yelloworange and pink colors. These were able to take up all 8 different substrates tested. This also applies to the samples from the sandy beach at List. In general, comparing these two biotopes, the pigmented bacteria colonies from the three Helgoland stations demonstrate greater uptake properties for the labelled substrates than those from List. Various brown pigmented bacteria found in the sublittoral sediments could also utilize all the substrates, whereas those of the same color group from List could not degrade glycerol tripalmitate (fat) or phenol.

\section{DISCUSSION}

If many representatives of the meiofauna play a large role as consumers of bacteria in nature, as suggested by Fenchel and Jørgensen (1977), the question arises as to what kinds of bacteria are available as food. The results of macro-autoradiographic studies on North Sea littoral and sublittoral sediments have shown that the saprophytic bacteria on the meiofauna 'menu' have the following characteristics: over $80 \%$ have uptake mechanisms for glucose, glucosamine, sodium acetate and aspartic acid. Approximately 1/3 can utilize glycollic acid; fewer numbers are able to degrade fat, phenol and uric acid. Bacteria which form yellow or orange pigmented colonies on agar occur frequently.

The numbers of saprophytic bacteria present range from $10^{4}$ to $10^{6}$ (g dry sediment) ${ }^{-1}$ or $\left(\mathrm{cm}^{3}\right.$ fresh sediment) $)^{-1}$, whereby the greatest concentrations are reached in sublittoral sediments consisting of very fine sand and mud. Relatively high amounts of bacteria are also available in coarser sublittoral sediments as well as in the mudflat zones of a sandy beach, while the smallest numbers are found on the lower and middle beach slope.

Although the physiological groups of saprophytic bacteria considered as a potential food source remained essentially the same in the sediments studied, the differences in the meiofauna populations were considerable. In the sublittoral sediments over $90 \%$ of the meiofauna present consisted of nematodes (Juario, 1975). In the sandy beach areas, on the other hand, the meiofauna is composed primarily of copepods, nematodes and tardigrades, all of which show definite preferences for certain zones of the beach slope or mudflats (Schmidt, 1968, 1969). Comparing available data on the meiofauna from these areas (Schmidt, 1968,
1969; Stripp, 1969a, b; Juario, 1975; Mielke, 1976), the greatest individual densities do not occur where the maximum numbers of saprophytic bacteria are found.

Thus, although high concentrations of bacteria are available as food, the distribution of the meiofauna may not be correlated to the kinds and numbers of saprophytic bacteria present in the sediments. It is possible, however, that the macro-autoradiographic method is not sensitive enough to detect small differences occurring within the bacteria populations, which may be of importance to the meiofauna. If so, the isolation and identification of as many bacteria as possible from a given sediment and the determination of their proportion of the bacterial biomass may be necessary, as well as laboratory experiments on the selective feeding of meiofauna using different bacteria strains, such as those currently here in progress.

Acknowledgements. Sincere thanks are extended to Professor Dr. G. Rheinheimer (Kiel) and to Dr. W. Gunkel (Helgoland) for critical reading of the manuscript, and to Dr. H.-G. Hoppe (Kiel) for helpful comments on the macro-autoradiographic method.

\section{LITERATURE CITED}

Brown, T. J. and Sibert, J. R. (1977). Food of some benthic harpacticoid copepods. J. Fish. Res. Bd Can., 34, 1028-1031.

Duncan, A., Schiemer, F. and Klekowski, R. Z. (1974). A preliminary study of feeding rates on bacterial food by adult females of a benthic nematode, Plectus palustris de Man 1880. Pol. Arch. Hydrobiol., 21, 249-258.

Fenchel, T. M and Jørgensen, B. B. (1977). Detritus food chains of aquatic ecosystems: the role of bacteria. $A d v$. microbial Ecol., 1, 1-58.

Gerlach, S. A. (1978). Food-chain relationships in subtidal silty sand marine sediments and the role of meiofauna in stimulating bacterial productivity. Oecologia (Berl.), 33, 55-69.

Gunkel, W. (1964). Die Verwendung des Ultra-Turrax zur Aufteilung von Bakterienaggregaten in marinen Proben. Helgoländer wiss. Meeresunters,, 11, 287-295

Gunkel, W. and Rheinheimer, G. (1968). Bestandsaufnahme: Bakterien. In C. Schlieper (Ed), Methoden der Meeresbiologischen Forschung. Fischer Verlag, Jena. pp. 142-157.

Hickel, W. and Gunkel, W. (1968). Untersuchungen über die Häufigkeit der Bakterien in der obersten Sedimentschicht der Deutschen Bucht in Beziehung zu den Substrateigenschaften. Helgoländer wiss. Meeresunters., 18, 213-231.

Hicks, G. R. F. and Grahame, J. (1979). Mucus production and its role in the feeding behaviour of Diarthrodes nobilis (Copepoda: Harpacticoida). J. mar. biol. Ass. U. K., 59, $321-330$.

Hoppe, H.-G. (1974). Untersuchungen zur Analyse mariner Bakterienpopulationen mit einer autoradiographischen Methode. Kieler Meeresforsch., 30, 107-116.

Hoppe, H.-G. (1977). Analysis of actively metabolizing bacterial populations with the autoradiographic method. In G. Rheinheimer (Ed.), Microbial Ecology of a Brackish Water Environment. Springer Verlag, Berlin. pp. 179-197. 
Juario, J. V. (1975). Nematode species composition and seasonal fluctuation of a sublittoral meiofauna community in the German Bight. Veröff. Inst. Meeresforsch. Bremerh., $15,283-337$

Mielke, W. (1976). Okologie der Copepoda eines Sandstrandes der Nordseeinsel Sylt. Mikrofauna Meeresboden, 59, $1-86$.

Oppenheimer, C. H. and ZoBell, C. E. (1952). The growth and viability of sixty-three species of marine bacteria as influenced by hydrostatic pressure. J. mar. Res., 11, 10-18

Rheinheimer, G. (1977). Bakteriologisch-ökologische Untersuchungen in Sandstränden an Nord- und Ostsee. Bot. Mar., 20, 385-400.

Riemann, F. and Schrage, M. (1978). The mucus-trap hypothesis on feeding of aquatic nematodes and implications for biodegradation and sediment texture. Oecologia (Berl.), 34, 75-88.

Rieper, M. (1978). Bacteria as food for marine harpacticoid copepods. Mar. Biol., 45, 337-345.

Schmidt, P. (1968). Die quantitative Verteilung und Populationsdynamik des Mesopsammons am Gezeiten-Sandstrand der Nordseeinsel Sylt. I. Faktorengefüge und biologische Gliederung des Lebensraumes. Int. Revue ges. Hydrobiol., 53, 723-779.
Schmidt, P. (1969). Die quantitative Verteilung und Populationsdynamik des Mesopsammons am Gezeiten-Sandstrand der Nordseeinsel Sylt. II. Quantitative Verteilung und Populationsdynamik einzelner Arten. Int. Revue ges. Hydrobiol., 54, 95-174.

Stripp, K. (1969a). Jahreszeitliche Fluktuationen von Makrofauna und Meiofauna in der Helgoländer Bucht. Veröff. Inst. Meeresforsch. Bremerh., 12, 65-94.

Stripp, K. (1969b). Die Assoziationen des Benthos in der Helgoländer Bucht. Veröff. Inst. Meeresforsch. Bremerh. $12,95-142$.

Weise, W. and Rheinheimer, G. (1979). Fluoreszenzmikroskopische Untersuchungen über die Bakterienbesiedlung mariner Sandsedimente. Bot. Mar., 22, 99-106.

Westheide, W. (1968). Zur quantitativen Verteilung von Bakterien und Hefen in einem Gezeitenstrand der Nordseeküste. Mar. Biol., 1, 336-347.

Weyland, H. (1967). Beitrag zur quantitativen Verteilung mariner und 'terrestrischer' Bakterien im Wasser und in Sedimenten der Deutschen Bucht. Helgoländer wiss. Meeresunters., 15, 226-242.

ZoBell, C. E. and Feltham, C. B. (1942). The bacterial flora of a marine mud flat as an ecological factor. Ecology, 23, $69-78$.

This paper was presented by Dr. W. Gunkel; it was accepted for printing on October 19, 1979. 